\title{
原著論文紹介
}

\section{IGFシグナルはゼブラフィッシュ初期胚における $\mathrm{GnRH}$ ニューロンの局在に必須である}

\author{
小 沼 健 (Department of Mol. Cell. Dev. Biol., University of Michigan)
}

E-mail: takeo@umich.edu

\section{1.はじめに}

「新たに生まれた神経細胞が、どのように して適切に配置され、機能を獲得するのか」 は、神経科学・発生学における命題の一つと いえる。生殖機能の基軸をなすゴナドトロピ ン放出ホルモン $(\mathrm{GnRH})$ ニューロンは、こ の問題に取り組むよいモデルである。GnRH ニューロンは嗅覚にかかわる部域に発生した のち、脳・視床下部へと移動することで下垂 体機能の制御系を形成する ${ }^{1,2)}$ 。この $\mathrm{GnRH}$ ニューロンの発生・移動は、魚類からヒトに いたる脊椎動物で広く共通してみられる現象 であり、生殖機能の獲得に不可欠な発達過程 として位置づけられる。だが、その制御機構 については不明な点が多い3）。

本論文では、インシュリン様成長因子 （IGF）の役割に着目した。IGFは体成長のシ グナル分子であり ${ }^{4)}$ 、サケ科魚類では $\mathrm{GnRH}$ と相互作用して性成熟の開始に関わる5）。ま たIGFは、神経細胞の生存・分化・移動を制 御し、神経系の発達に重要な成長因子である 6,7)。これらの背景から「GnRHニューロン の発生に IGFシグナルが関わる」という仮説 を立て、ゼブラフィッシュの胚を用いて検討 した。その結果、IGFシグナルが初期胚にお ける GnRH3ニューロンの正常な局在に必須 であることを証明した。

\section{IGFシグナルが $\mathrm{GnRH}$ ニューロンの発生 を制御する}

ゼブラフィッシュには二種類の $\mathrm{GnRH}$ ニ ューロン、 GnRH2ニューロンと GnRH3ニ
ューロンが存在する。GnRH2ニューロンは 中脳に局在するが、GnRH3ニューロンは嗅 球に発生し、視床下部へと移動する。どちら も受精後26〜32時間より発生する ${ }^{8,9)}$ 。

この発達過程にIGFシグナルが関わるの か調べるため、IGF1受容体の機能阻害実験 を行った。熱刺激により dominant-negative IGF1受容体を発現するトランスジェニック 系群 ${ }^{10)}$ を用い、初期肧における IGFシグナ ルを阻害した。その結果、GnRH2ニューロ ン、GnRH3ニューロンのいずれも発生が遅 延することが分かった。

次に、GnRH3のプロモーター活性を EGFPで可視化した系群 ${ }^{11)}$ と掛け合わせた肧 を作成し、GnRH3ニューロンの発達過程を 追跡した。その結果、IGFシグナルを阻害し た胚では、GnRH3ニューロンが嗅球だけで なく他の脳部域にも発生し、不可逆的に脳内 分布が異常になった(図1)。一方、他の嗅覚 細胞や GnRH2ニューロンの分布は変化しな かった。

\section{3. 発生初期のIGFシグナルがGnRH3ニュー ロンの局在に重要である}

では、IGFシグナルは「いつ」GnRH3ニュ ーロンの脳内分布を制御するのだろうか?

肧発生の初期 (受精後4時間以降) にIGF1受 容体を阻害すると、半数以上の肧で異所性の $\mathrm{GnRH} 3$ 細胞が発生した。一方、胚発生の後 期 (受精後30時間以降)にIGFシグナルを阻 害しても、GnRH3ニューロンの分布は変化 しなかった。すなわち、このIGFシグナルの 

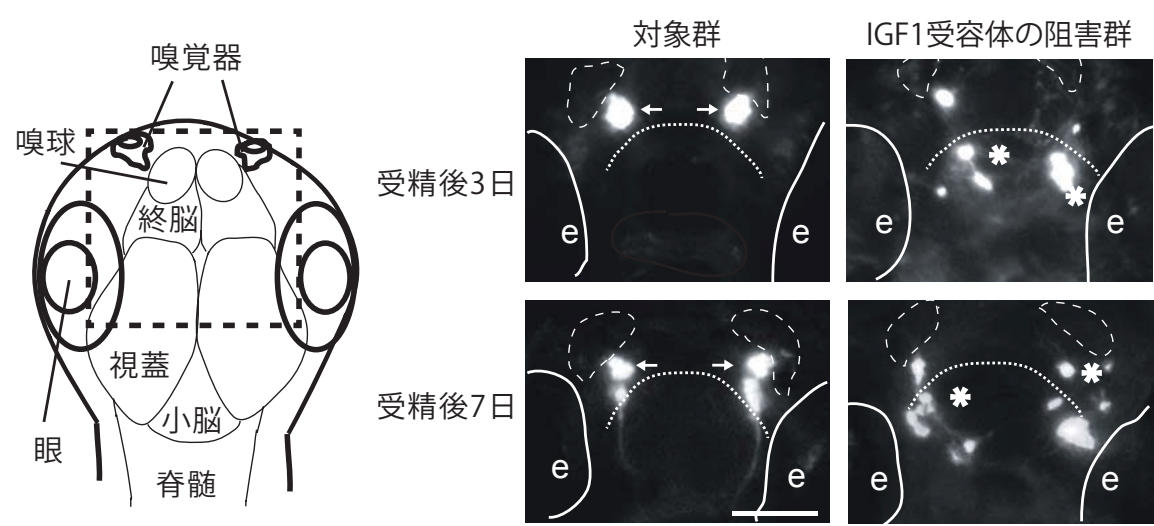

図1 GnRH3ニューロンの脳内分布

左図 : ゼブラフィッシュ脳の概略。点線で囲った領域を右図で示した。右図 : GnRH3ニュー ロンの分布。正常な肧では GnRH3ニューロンが嗅覚器 (破線) の近傍に集団を形成する (矢印 で示す)。IGF1受容体を阻害した肧では GnRH3ニューロンの局在が乱れている。ここでは一 例のみを示す。嗅球と終脳の境界を点線で示した。

作用は、発生初期に特異的なものといえる。

\section{4. 新生GnRH3ニューロンの局在にかかわ る細胞・分子機構}

最後に、IGFシグナルが「どこで、どのよ うな機構で」新生 GnRH3ニューロンの局在 を制御するのか調べた。ゼブラフィッシュ では、GnRHニューロンが頭部神経冠の細 胞より発生することが報告されている12,13)。 そこで神経冠細胞のマーカー遺伝子である sox10の発現を調べたところ、IGFシグナル を阻害した肧では、頭部神経冠でみられる sox10の発現細胞数が減少することが分かっ た。

IGF1受容体の主要な細胞情報伝達系は、 PI3 kinase-Akt経路 と、Ras-MEK1/2-Erk1/2 経路の二つである ${ }^{4)}$ 。PI3 kinaseの阻害剤の 存在下で培養した肧では、IGF1受容体を阻 害した胚と同様に、異所性の GnRH3ニュー ロンが発生した。この効果は MEK1/2の阻害 剤では見られなかった。

\section{5. まとめ}

本研究により、初期発生時における IGFシ グナルが、新生 GnRH3ニューロンの正常な 局在に不可欠であることが分かった。IGFは、 IGF1R-PI3K経路を介して頭部神経冠に作用
することで、GnRHニューロン前駆細胞の 移動または分化を制御していると考えられる (図2)。現在、この仮説をさらに検証するた め、神経冠細胞の動態に着目した解析を開始 している。

本論文は、Regulation of Temporal and Spatial Organization of Newborn GnRH neurons by IGF Signaling in Zebrafish (Onuma TA, Ding Y, Abraham E, Zohar Y, Ando H, Duan C) と題して、The Journal of Neuroscience (2011) 31(33), 11814-11824に公表した。

\section{文 献}

1 ) Schwanzel-Fukuda M, Pfaff DW, 1989. Origin of luteinizing hormone-releasing hormone neurons. Nature, 338, 161-164.

2 ) Wray S, Grant P, Gainer H, 1989. Evidence that cells expressing luteinizing hormonereleasing hormone mRNA in the mouse are derived from progenitor cells in the olfactory placode. Proc. Natl. Acad. Sci. USA, 86, 8132-8136.

3 ) Wierman ME, Kiseljak-Vassiliades K, Tobet S, 2011. Gonadotropin-releasing hormone (GnRH) neuron migration: Initiation, maintenance and cessation as critical steps to ensure normal reproductive function. Front. Neuroendocrinol., 32, 43-52.

4 ) Duan C, Xu Q, 2005. Roles of insulin-like 
表現型
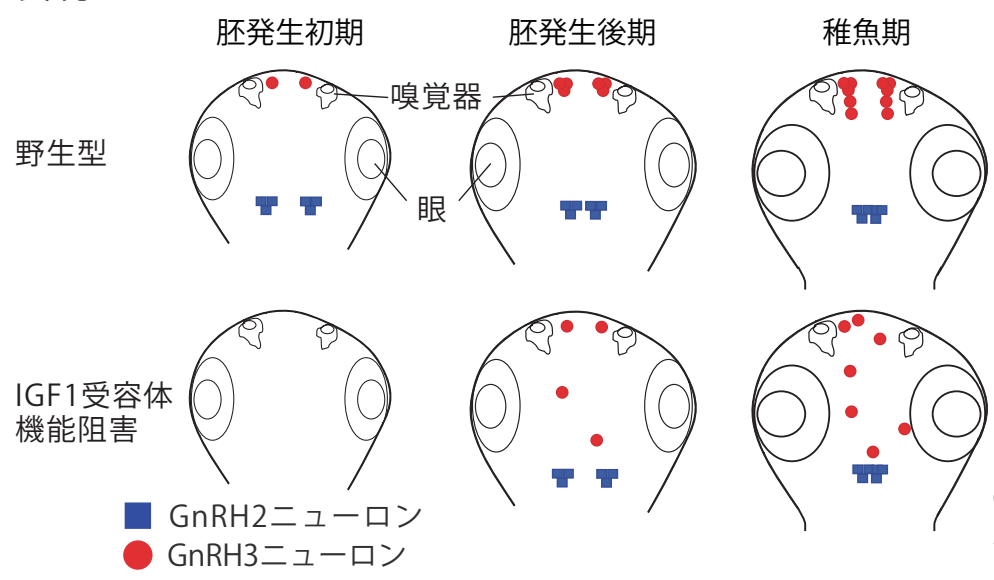

分子機構

図2 IGFシグナルによるGnRHニューロンの発生制御機構

growth factor (IGF) binding proteins in regulating IGF actions. Gen Comp Endocrinol, 142, 44-52.

5 ) 安東宏徳，小沼健，浦野明央，2009, GnRHに対する反応性の分子制御とサケの 産卵回遊、比較内分泌学, 132, 7-23.

6 ) Schlueter PJ, Peng G, Westerfield M, Duan C, 2007. Insulin-like growth factor signaling regulates zebrafish embryonic growth and development by promoting cell survival and cell cycle progression. Cell Death Differ 14, 10951105.

7 ) Joseph DA, Ye P, 2008. Expanding the mind: insulin-like growth factor I and brain development. Endocrinology 149, 5958-5962.

8 ) Gopinath A, Tseng LA, Whitlock KE, 2004. Temporal and spatial expression of gonadotropin releasing hormone $(\mathrm{GnRH})$ in the brain of developing zebrafish (Danio rerio). Gene Expr. Patterns 4, 65-70.

9) Palevitch O, Kight K, Abraham E, Wray S, Zohar Y, Gothilf Y, 2007. Ontogeny of the GnRH systems in zebrafish brain: in situ hybridization and promoter-reporter expression analyses in intact animals. Cell Tissue Res
327, 313-322.

10) Kamei H, Ding Y, Kajimura S, Wells M, Chiang P, Duan C, 2011. Role of IGF signaling in catch-up growth and accelerated temporal development in zebrafish embryos in response to oxygen availability. Development 138, 777 786.

11) Abraham E, Palevitch O, Ijiri S, Du SJ, Gothilf Y, Zohar Y, 2008. Early development of forebrain gonadotrophin-releasing hormone (GnRH) neurons and the role of $\mathrm{GnRH}$ as an autocrine migration factor. J. Neuroendocrinol 20, 394-405.

12) Whitlock, KE, Wolf, CD, Boyce, ML, 2003. Gonadotropinreleasing hormone (gnrh) cells arise from cranial neural crest and adenohypophyseal regions of the neural plate in the zebrafish, Danio rerio. Dev. Biol. 257, 140152. 10) Kamei H, Ding Y, Kajimura S, Wells M, Chiang P, Duan C, 2011.

13) Whitlock KE, Smith KM, Kim H, Harden MV, 2005. A role for foxd3 and sox10 in the differentiation of gonadotropinreleasing hormone $(\mathrm{GnRH})$ cells in the zebrafish Danio rerio. Development 132, 5491-5502. 